\title{
SpS13: High-precision tests of stellar physics from high-precision photometry
}

No contribution was received from this Joint Discussion. 